\title{
ANSERJ
}

Vol. 4, No 1

Spring / Printemps, 2013

pp. $43-65$

Canadian Journal of Nonprofit and Social Economy Research

Revue canadienne de recherche sur les OBSL et l'économie sociale

\section{Flooding Hope and Livelihoods: Lake St. Martin First Nation}

\author{
Myrle Ballard \& Shirley Thompson
}

\author{
University of Manitoba
}

\begin{abstract}
Lake St. Martin First Nation, a community situated in the Interlake Region of Manitoba, was permanently displaced in 2011. After they were flooded out of their ancestral lands and left homeless, the Province of Manitoba further disempowered the members of the community by refusing to listen to their preference for a new site. That a nearby Cold War radar base was selected by the Province as an interim location, against the wishes of the community, further victimized the members and left them in limbo. This article, incorporating both Indigenous and Western methodologies, examines the consequences of community displacement on sustainable livelihoods, homes, health, and sociocultural integrity in the Lake St. Martin First Nation.
\end{abstract}

\section{RÉSUMÉ}

La Première Nation de Lac St-Martin, une communauté autochtone de la région Entre-les-Lacs au Manitoba, a été déplacée en permanence en 2011. Une inondation a couvert ses terres ancestrales et a laissé ses membres sans domicile. Le gouvernement manitobain a diminué encore plus le pouvoir de ceux-ci en refusant de tenir compte de leurs préférences pour un nouveau site. II a exacerbé leur statut de victime en choisissant un emplacement intérimaire contre leur gré - une ancienne base radar à proximité utilisée pendant la Guerre froide - les laissant ainsi dans une situation incertaine. Cet article, recourant à des méthodologies autochtones et occidentales, examine les conséquences du déplacement de cette communauté sur le travail, le logement, la santé et l'intégrité socioculturelle de ses membres.

Keywords I Mots Clés : Flooding; Displacement; Community development; Sustainable livelihoods; Indigenous; First Nation; Relocation / Inondation; Déplacement; Développement communautaire; Travail durable; Autochtone; Première Nation; Relocalisation 
Lake St. Martin First Nation (FN), a community of 2394 people (Aboriginal Affairs and Northern Development Canada, 2012), was permanently displaced in May, 2011 by a devastating "superflood" (Galloway, 2012). More than two years later, the community continues to be without a land base. Considered the "largest spring runoff in the province's history" (Galloway, 2012), the geographical scope and duration of the 2011 flood also surpassed previous provincial records (Province of Manitoba, 2012). The Manitoba provincial government elevated the water levels by using a water control structure. The result was that people with a deep ancestral and spiritual connection to the land were displaced, while cottages and agricultural land used by people with only economic and recreational interests, were salvaged (Galloway, 2012). In 2011, "[the] water [at Lake St. Martin] peaked at 806 feet, almost 3 feet higher than the historic peak of 1955" (KGS Group and AECOM, 2011, p. 2; see Figure 1), which flooded the three reserves adjacent to Lake St. Martin, but hit Lake St. Martin FN the hardest.

Figure 1: Flood water levels in 2011 and 2012 at Lake St. Martin Lake St Martin Observed Water Levels in Feet 2011 - 2012

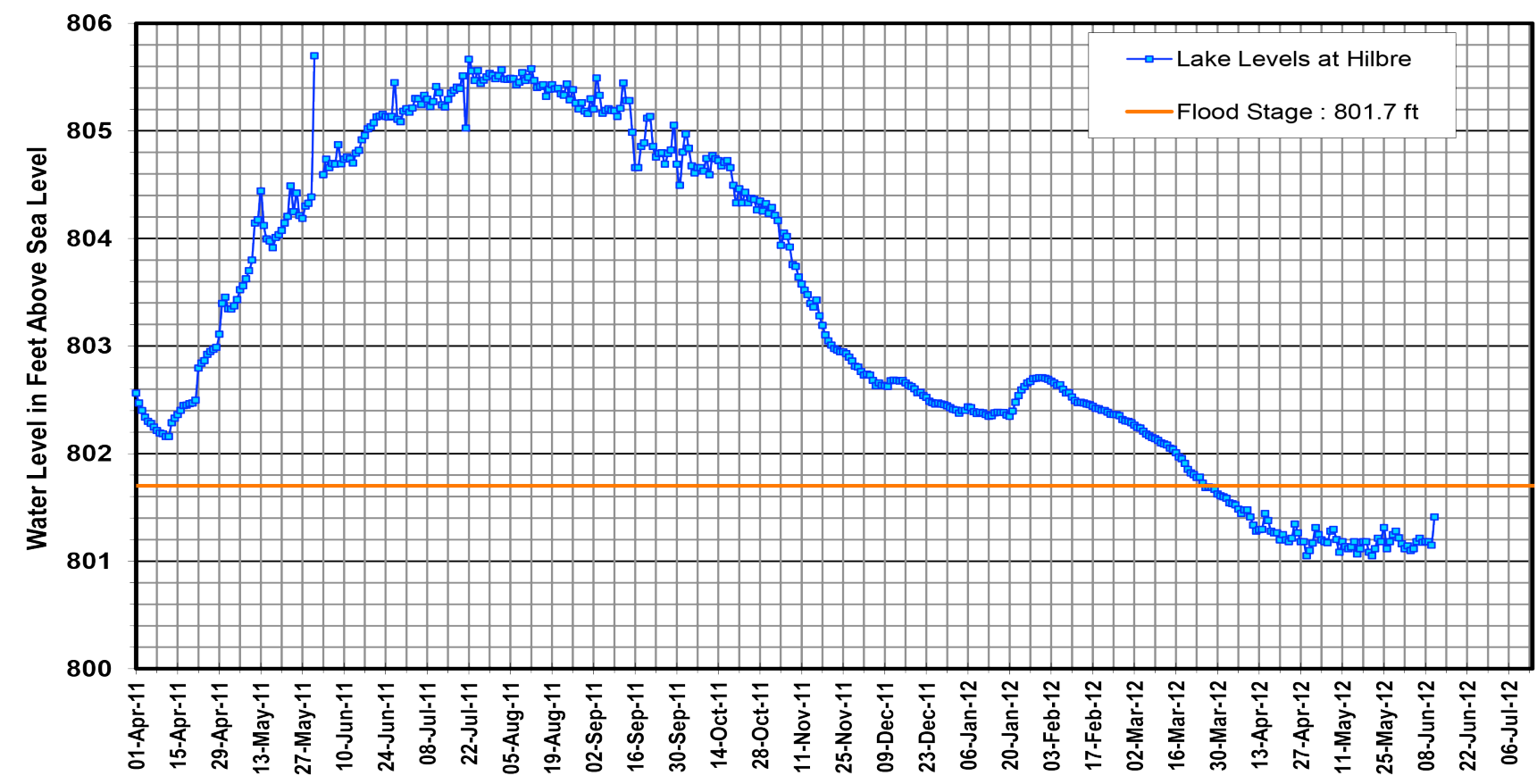

Source: Province of Manitoba (2012)

The water level in Lake St. Martin was increased to reduce levels on Lake Winnipeg, thereby protecting cottagers and farmers on both the Assiniboine River and Lake Manitoba at the expense of the people and houses of Lake St. Martin FN (Galloway, 2012). A report commissioned by the Province regarding the 2011 flood stated:

If no action is taken, extremely high water levels on Lake Manitoba and Lake St. Martin are expected to continue for an extended duration, leaving communities, homes ... at high risk of further damage from flooding, wind and waves. The spring break-up of lake ice at such elevated water levels also has the potential to cause devastating damage to properties around the lakes. (KGS Group and AECOM, 2011, p. 2). 


\section{Ballard \& Thompson (2013)}

The research presented in this article evolved from Dr. Ballard's PhD dissertation on her home community of Lake St. Martin FN. Specifically, this article documents the impact of the 2011 flood on Lake St. Martin FN community and their struggle for a new community with pimachiwiin, an Anishinaabe word meaning looking after the next seven generations, or sustainable living.

Lake St. Martin FN was part of a larger group of some 4,525 FN people in Manitoba-displaced from $17 \mathrm{FN}$ communities-who were impacted by the 2011 flood. According to a Southern Chiefs' Organization (SCO) resolution in May 2012: "there are currently 2,427 displaced evacuees from the eight affected communities, which comprise of two (2) Southern First Nations completely evacuated and unable to return to their respective community with six other communities" (SCO, 2012, p. 1). Lake St. Martin FN was one of two communities to be completely evacuated.

\section{History and description of Lake St. Martin First Nation}

Lake St. Martin FN is an Anishinaabe community located in the Interlake region of Manitoba, Canada, $225 \mathrm{~km}$ northwest of Winnipeg. The community is situated on the northwest shore of Lake St. Martin. The community lacks paved road access, but is accessible by the gravel Provincial Road \#513 and then by a $10 \mathrm{~km}$ dirt road. The Lake St. Martin FN Reserve is situated in boreal forest, and its geomorphology consists of intermittent karst topography and soluble limestone bedrock.

The Anishinaabe people of Lake St. Martin FN have lived on the shores of Lake St. Martin for many generations. Traditionally, the people of Lake St. Martin were mainly fishers and buffalo hunters, although they pursued other hunting and agricultural activities. Women would get together to prepare the fishing nets and men made canoes for travel and fishing. In 1871, Lake St. Martin took part in Treaty 2, leading to the creation of Reserve No. 49, and Treaty 5, leading to the creation of Reserve No. 49A. As a result of these two treaties, the people of Lake St. Martin FN were forced to occupy a very small land base of less than 24 square kilometers (Aboriginal Affairs and Northern Development Canada, 2012), which was only a small part of their traditional territory. Treaty No. 2 was negotiated and agreed to at Manitoba House in August, 1871. First Nation communities that entered into Treaty No. 2 include: Dauphin River, Ebb \& Flow, Keeseekoowenin, Lake St. Martin, Lake Manitoba, Little Saskatchewan, O-Chi-Chak-Ko-Sipi, Pinaymootang, and Skownan (Ballard, 2012). Canadian settler communities that came to own land that originally belonged to FN peoples and that share in Treaty No. 2 obligations include: Dauphin, Melita, Minnedosa, Roblin, and Virden.

After settlement started in the mid-1850s, fishing, apart from being an important source of sustenance, provided an income for the Anishinabek peoples. Despite diminishing resource access due to settlers' superior technology and their ability to overharvest for export, and by settlement reducing wildlife populations (Ballard, 2012), the community of Lake St. Martin FN adapted to their new circumstances, retaining their language, having a day school rather than a residential school, and practicing agriculture to maintain their food selfsufficiency. At Lake St. Martin FN, people lived sustainably until the mid 1960s when a water control structure increased water levels and flooded their land. While the Portage Diversion moved water from the Assiniboine River to Lake Manitoba and the Fairford River, the Fairford control structure on the Fairford River diverted water from Lake Manitoba to Lake St. Martin. Lake St. Martin's outlet, the Dauphin River, which leads to Lake Winnipeg (see Figures 2 and 3), has higher water levels (Traverse, 1999). Thus, Lake St. Martin became a reservoir. Figure 3 shows how Lake St. Martin is overflowing its banks, while the Dauphin River in the northwest corner of the map is not. 
Ballard \& Thompson (2013)

Figure 2: Lake St. Martin First Nation's location in the Interlake of Manitoba, Canada

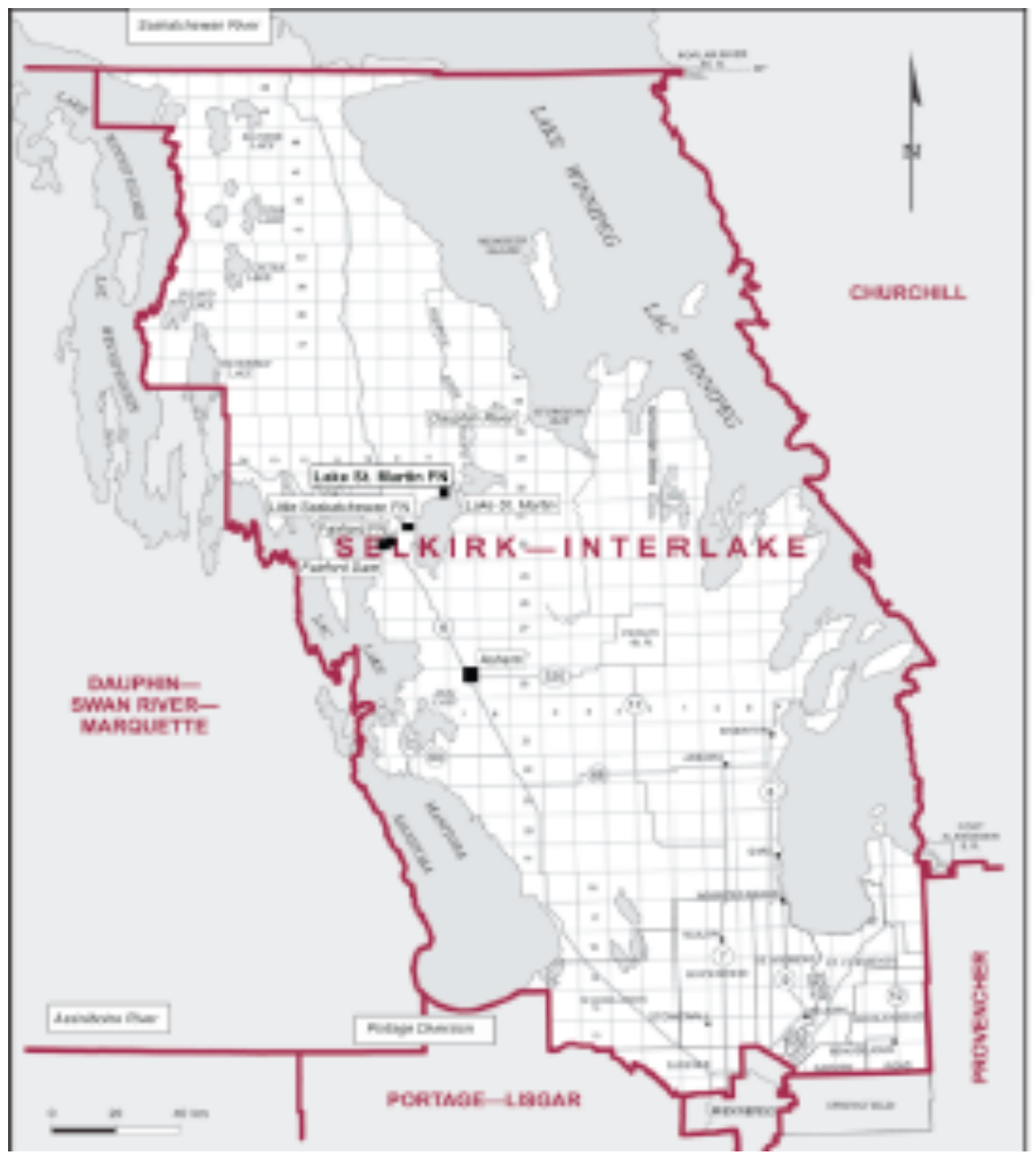

Source: Revised by Chan and Thompson 2013 based on Province of Manitoba, 2009 
Ballard \& Thompson (2013)

Figure 3: Flooding levels on Lake St. Martin

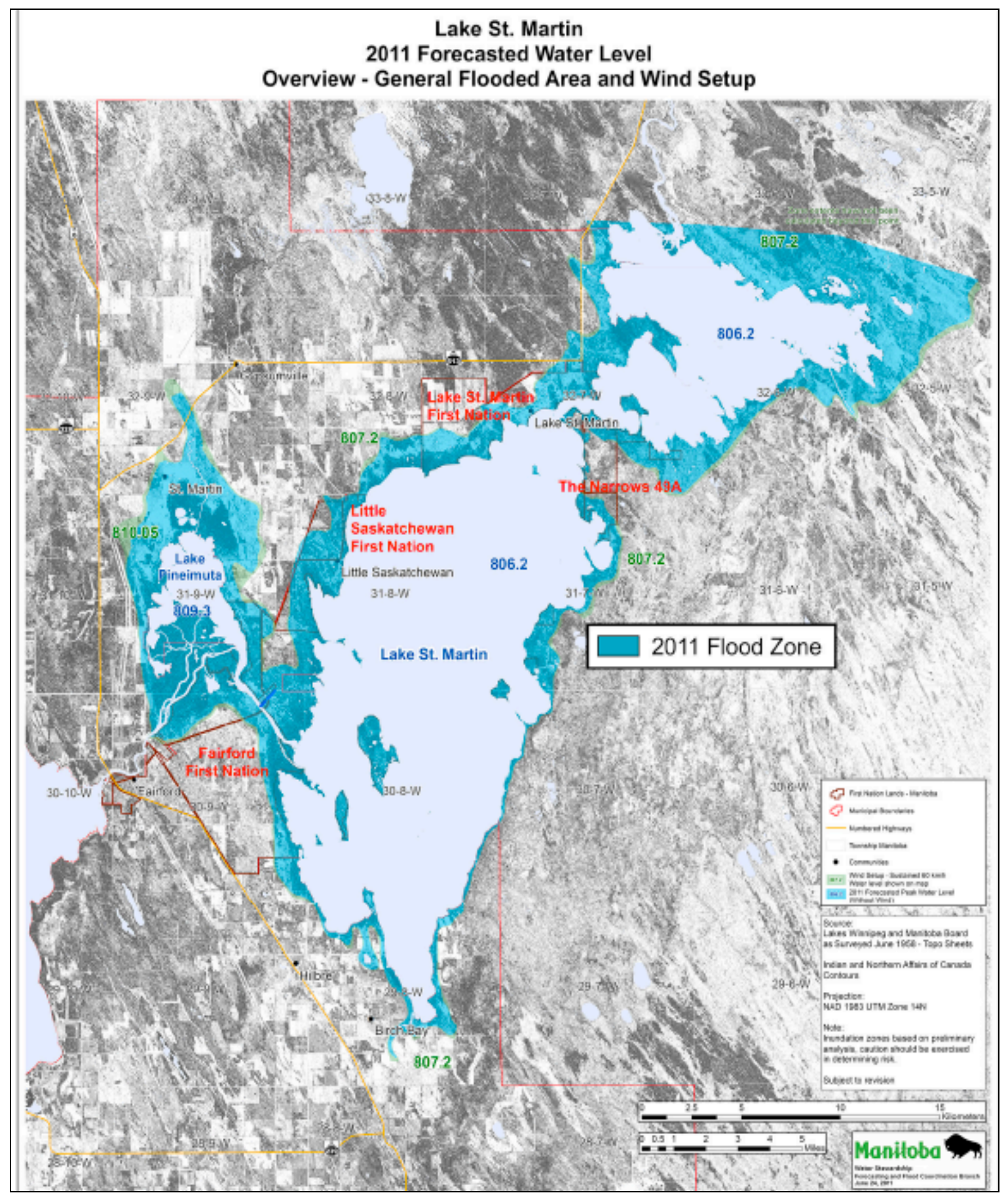

Source: Province of Manitoba, 2011 


\section{Ballard \& Thompson (2013)}

Lake St. Martin FN was negatively impacted by the Fairford water control structure, constructed in 1961, as it flooded out agricultural activities and diminished fishing livelihoods at Lake St. Martin FN (Traverse, 1999). The construction and operation of the water control structure were carried out by the Province of Manitoba, without FN communities being warned, consulted, or compensated (Ballard, Klatt, \& Thompson, 2012). Slowly, as the water levels rose and more water was sent into Lake St. Martin, annual spring flooding impacted most of the community's housing stock, and generally higher water levels permanently saturated lands underneath the Reserve (Traverse, 1999). In 1970, the second water control structure, the Portage Diversion, was constructed to keep the City of Winnipeg safe and dry and led to the increased elevation of water levels in Lake St. Martin. From 1961 until today, hectares of hayfields and beach land on the reserve have gradually disappeared due to the higher water levels (Traverse, 1999).

As water levels increased each year since the 1960s, so too did poverty at Lake St. Martin FN. The community did, however, manage to retain its social cohesion, culture, and housing. At the time of the 2011 flood, the nearest town, Gypsumville, located approximately $10 \mathrm{~km}$ from Lake St. Martin FN, with a population of approximately 100 people, had paved roads, a full grocery and hardware store, fire hall, hotel, post office, police station, a provincially funded health care centre, and a town hall. Meanwhile Lake St. Martin FN, lacked these services and infrastructures, despite having a population more than ten times as large. As the increasingly flooded Reserve offered no viable means of economic development, Lake St. Martin FN community members have thus had to rely on services in Gysumville.

The Fairford control structure played a key role in the 2011 "superflood." With high water levels on the Assiniboine River, the water control structure was opened to its maximum to divert water to Lake St. Martin. This diversion had significant impacts on Lake St. Martin FN, and others. The water levels started to rise during the winter of 2011 / 2012 reaching a peak of 817.5 feet above sea level (KGS Group and AECOM, 2011). Figure 3 shows how the only road to Lake St. Martin FN and the two other FN communities on the lake was flooded out, as well as the communities' housing, located by the lake, were underwater. It is also apparent in Figure 3 that Lake Manitoba and the areas upstream of Lake St. Martin do not experience the same high water levels. This water diversion structure is operated by the Province of Manitoba to protect Lake Manitoba cottagers and farmers from flooding by diverting waters to Lake St. Martin (Province of Manitoba, 2012). On May 8, 2011, unprecedented water levels forced the evacuation of the entire community of Lake St. Martin FN. In the spring of 2013 the community remains evacuated with no land base, and no hope for return. People have been living in hotels throughout Winnipeg and other parts of the Manitoba for almost two years, with a permanent community site yet to be established.

\section{The long history of flooding First Nation communities in Manitoba}

Government and hydro projects flooding FNs is not a new phenomenon. Hydro dams have previously disempowered and displaced FNs communities situated along the path and flows of hydro dams in the name of development. One such example is the relocation of the Chemawawin Cree when Manitoba Hydro began damming the Saskatchewan River to start the development of the Grand Rapids generating station (Loney, 1995). The cumulative impact of altered water levels caused a giant reservoir to form on Cedar Lake, thereby destroying the livelihoods of the people, the habitats of species that provided sustenance for those people, and ultimately forcing the relocation of the community of Chemawawin.

In his book called As Long as the Rivers Run, Waldram (1993) quotes a FN person who gave testimony for the 


\section{Ballard \& Thompson (2013)}

Manitoba Hydro Easterville brief:

We want to tell a story, our story, of what can happen to Indian people when their land is flooded by a hydro project and their way of life is forced to change... It is only ten years since we left the home we had chosen about one hundred years ago when the white men first came into our country and told us that we must give up our land and settle down to live on a reserve which we chose at that time. We were told that this reserve would be our home as long as the sun shines, the river flows and the grasses grow (Waldram, 1993, p. 3).

The community of Easterville was flooded by the Grand Rapids Dam, which was completed in 1964 on the Saskatchewan River near the community of Grand Rapids. What happens to the promise "as long as the rivers run", when the rivers no longer flow? Waldram indicates that flooding constitutes breaking of the treaties asking: "When Indian reserve land has been flooded, has the spirit of the treaties been broken?" (Waldram, 1993, p. 4).

Since time immemorial, the rivers, lands, and lakes were occupied and used by the original peoples of Canada, believing that the waterways were given to them by the creator (Waldram, 1993). To FN peoples, water is considered life and the rivers are considered the veins of Mother Earth. Some legal cases have even shown that FN peoples have riparian rights (Waldram, 1993). However, the Province of Manitoba and their utilities have taken the view that waterways are a common property resource and that FN peoples have no special rights to them, and thus dams are developed to create hydro electricity for the "common good."

In Manitoba, many other FN communities have been flooded due to hydro damming. Damming the Nelson River reversed its flow and increased water levels, displacing the South Indian Lake FN community (Thompson et al, 2011a). The ability of FN peoples to live off the land has been compromised at South Indian Lake FN and other communities, with South Indian Lake fishers reporting catching four tubs of fish with 40 nets when before they caught 40 tubs with four nets (Thompson et al, 2011b).

\section{Community Development Planning}

Community development is a process whereby: "communities [address] problems and opportunities, on their own behalf, which they perceive to be of importance to their quality of life or their community's viability" (Douglas, 1994, p. 10). Community development planning consists of a participatory and usually interactive form of planning and design (Hoch, Dalton, So, and ICMA, 2000). "Community" is a broad term that requires planning to consider the local infrastructure, services, expertise, and natural resources that are available (Shragge, 2003). Self-sufficiency, local decision-making, and community ownership are priorities in community development (Loxley, 1986). Diverse community members help to determine the goals, objectives, planning, funds / resource identification, documentation, and direction of planned project implementations (Hoch et al, 2000). At a minimum, community consensus is sought for proposed allocations of scarce resources among competing demands. However, access to a wide range of planning tools can be applied to allow community members to shape the local plan content, and to influence development budgets and projects, and thus future infrastructure and land uses (Hoch et al, 2000).

To be sustainable, a community plan should consider how a community can meet their own needs whenever possible (Maser, 1996). Clearly, Lake St. Martin FN's land base is no longer able to meet community needs, and there is a need for community development. The needs of Lake St. Martin FN are many, including the establishment of a permanent land base and infrastructure. Douglas (1994) considers community involvement asking some key questions: What is being developed? By whom? How is it being developed? And on whose behalf? These are all key questions that need to be asked within the context of a strategic analysis framework. 


\section{Ballard \& Thompson (2013)}

\section{Strategic Analysis Framework}

A strategic analysis was undertaken to weigh choices in a complex and shifting situation with the goal of sustainable community and livelihoods development. This strategic analysis tool has previously been used in regional development and municipal planning (Halla, 2007; Terrados, Almonacid, and Hontoria, 2007; Vonk, Geertman, and Schot, 2007). Sustainable development considers those capitals or assets (natural, physical, human, financial, and social; Chambers \& Conway, 1991; Department for International Development, 2001, 2008; IMM, 2008; Clark \& Carney, 2008) that determine quality of life (Ellis, 2000), at household (Scoones, 1998) and community levels (Thompson et al., 2011a; Ballard, 2012).

A sustainability analysis is generally absent from community development evaluation (Brocklesbury and Fisher, 2003). In this study, sustainable livelihoods assets (human, social, natural, physical and financial) are modified to PESCE (political, economic, social, cultural, and environment), in a modified version of the sustainable livelihoods framework. This modified framework was analyzed to determine impacts, and judge the different development options for Lake St. Martin FN in addressing the flood impacts. These frameworks, the strategic analysis and sustainable livelihoods framework, were assessed for their practicality in addressing the flood impacts. The medicine wheel did not provide a critical analysis that was needed in this research. It is our view that Indigenous research also should not be limited to one methodology.

The five key sustainable livelihoods assets in Lake St. Martin are profiled here:

1. Human capital (that is, the skills, health, and education of individuals that contribute to the productivity of labor and capacity to manage land) is limited, given the relatively low levels of education, high rates of chronic unemployment, and high rates of disease compared to other communities in Canada (Aboriginal Affairs and Northern Development Canada, 2012) However, traditional knowledge is still abundant among elders and traditional livelihoods users (i.e., those who live off the land).

2. Social capital (that is, the close social bonds that facilitate cooperative action, social bridging, and linking to share and access ideas and resources), once strong, has been weakened by the colonial day school system, reserve settlements, the "sixties scoop" (e.g., government practice starting in the 1960s and continuing through the late 1980s, of apprehending high numbers of FN children to send to foster homes or put up for adoption usually into white families), and the settler education (LaDuke, 2002). This apartheid, where FN people were restricted to reserves and oppressive policies, resulted in few opportunities for Aboriginal peoples to influence policies, programs, and their own development (Thompson et al., 2011a; Ballard, 2012).

3. Natural or environmental capital (that is, resources and land management practices) is limited, as FNs have no regulatory or ownership rights to resources in their territories (Thompson et al., 2011a, b; Ballard, 2012; LaDuke, 2002).

4. Physical capital (that is, equipment and infrastructure) is inadequate in Lake St. Martin FN with only gravel roads, and lacking adequate healthy housing, safe drinking water, stores, industrial or employment facilities, and without even a community centre, despite its large population. 


\section{Ballard \& Thompson (2013)}

5. Financial capital (that is, savings and credit) is generally low, as community lands and housing is the property of the Crown (Ballard, 2012); without collateral, FN peoples have limited ability to obtain credit to build enterprise.

The sustainable livelihood framework also considers political assets and other aspects in its general framework. Creating barriers to or facilitating sustainable livelihoods, are the pervasive institutional structures (e.g., rules, customs, and land tenure) and processes (e.g., laws, policies, societal norms, and incentives), which operate at multiple levels (e.g., regional, government, and multinational corporations; Carney, 1998, 2002; Ellis, 2000; Scoones, 1998). Institutional structures such as the Indian Act, and other colonial policies that continue to this day, take away local decision-making powers, and have resulted in a state in which Lake St. Martin FN has been under third party management for over 10 years (Ballard, 2012). Third party management is a requirement of the federal government whereby external accounting firms control a FNs internal funding and management.

Cultural capital (language, spirit, close bonds that facilitate cooperative action and sharing of ideas and resources) and Indigenous worldview are what make FN communities and individuals strong. Future development in FN communities must consider cultural priorities (Ballard, 2012; Ballard et al, 2012; DavidsonHunt, Turner, Mead, Cabrera-Lopez, Bolton, Idrobo, Miretski, et al, 2012) and be based in the Indigenous worldview, which incorporates cyclical thinking, reciprocal relations, responsibilities to the earth and creation, and decentralization (Ballard, 2012). LaDuke (2002, p. 79) states that Indigenous communities should be based on the Indigenous concept of Minobimaatisiiwin, an Anishinaabe word meaning the "good life" of "continuous rebirth."

\section{Methodology}

This study incorporates both Indigenous and Western methodologies. The Indigenous research methodologies undertaken included storytelling, experiencing traditional activities, and visiting. One of the co-authors is a member of Lake St. Martin FN, and spent the first 18 years of her life living in the community. She worked for the community at the time of this research and has strong ties to the community, with her mother and many relatives and friends still living in Lake St. Martin FN. A long-term relationship with the community, and being able to speak the language were invaluable during this vulnerable period in the people's lives. On-going communication was maintained with the community to validate the initial research findings.

Traditional activities that the co-author participated in, as a community member, included Seneca root digging, berry picking, and preparing fish, moose, deer, and goose. As well, cultural activities included family outings and gatherings, community feasts, and wake services and burials.

Western research methods included 12 interviews with Elders, two focus groups, four workshops on strategic analysis, and community planning. Four different community workshops / forums were held in Lake St. Martin FN and Winnipeg. The involvement of school children and youth from Lake St. Martin FN resulted in their drawing and telling their stories.

\section{Participatory Video}

Participatory video research allowed the people of Lake St. Martin FN to tell their story, often in their own language. This method values and validates oral culture (Thompson and Lozeznik, 2012). For the participatory video interviews, written consent was obtained to identify participants by name. Draft versions of the film were screened at different events to provide community members on-going input into the storyline. After the screenings, more interviews and scenes were added based on community input. 


\section{Ballard \& Thompson (2013)}

The video was widely circulated using Facebook and social media campaigns. The film, Flooding Hope was featured in Intercontinental Cry International and the Winnipeg Free Press. As well, in an effort to influence policy, the film was shown at film festivals, more than 20 workshops and conferences, at the Provincial Legislature in Manitoba, and at the Assembly of First Nations Chiefs gathering in Ottawa.

\section{PESCE Strategic Analysis}

A strategic analysis was carried out in workshops with the Anishinabek from Lake St. Martin FN, creating a list of priorities for their quality of life and the viability of their new community. The modified sustainable livelihoods framework addressed the need for sovereignty in decision-making to consider political, economic, social, cultural, and environmental needs / capitals, or PESCE (Wakefield and Cottone, 1986). The flood impacts were analyzed using interview and workshop data and applied to each category. The alternative relocation sites were analyzed to assist Lake St. Martin FN to identify a preferred site for community development.

\section{Analysis of Different Sites by PESCE}

An analysis of the three rural sites proposed by the Province of Manitoba were assessed by band staff, chief, and council, in additional to the four sites proposed by the community (two rural and two urban). This preliminary analysis of five rural sites was taken to the community for input. The urban sites were not considered for permanent occupation, but as possible temporary sites. Lake St. Martin FN developed criteria for judging the sites that augmented the Province's very limited analysis which was only based on three criteria: road access (existing road), infrastructure, and easement. The list of criteria developed by the community grew as community members contributed items they felt were important. The federal government, who has a trust responsibility for "Indians and Lands Reserved for Indians", did not meet their responsibility to act in the best interest of the community. The federal government participated as an "observer," but also sanctioned the Province to monopolize a relocation process that was against the expressed wishes and best interests of Lake St. Martin FN.

Community criteria included language, gendered needs, political sovereignty, sustainability, and Anishinaabe Knowledge Systems (AKS) as priorities for site analysis. The Lake St. Martin FN list prioritized cultural aspects, including Anishinaabe language considerations, new economic development opportunities, as well as traditional sustainable livelihoods activities such as hunting, fishing, and berry picking. Also, community members' gendered needs throughout their entire life cycle were considered including youth, mothers, families, and elderly. The analysis (see Table 1) was discussed and reviewed by chief and council and community members and revised until the analysis was considered acceptable to the community. The analysis in Table 1 was presented at the relocation meetings with the Provincial and Federal governments, prior to the Province's unilateral decision regarding relocation to the site that the community considered least acceptable.

A PESCE analysis was used both during workshops to record how the flood impacted the community, and to judge the best site for development. The PESCE tool provided the Anishinabek with a way of organizing and thinking about the assets or capitals needed to create a sustainable livelihoods and a high quality of life for community members. The flood impacts on political, environmental, social, cultural, and economic aspects are divided into different sections. 
Ballard \& Thompson (2013)

Table 1: PESCE Analysis for Lake St. Martin First Nation Permanent Site

\begin{tabular}{|c|c|c|c|c|c|c|c|}
\hline \multicolumn{8}{|c|}{ PESCE Analysis (Physical, Environment, Social, Cultural, Economic) } \\
\hline $\begin{array}{l}\text { Site Name I } \\
\text { Number }\end{array}$ & $\begin{array}{l}\text { Pinemuta } \\
\text { Radar base } \\
\text { (interim site) }\end{array}$ & Halaburda & Rohl & $\begin{array}{l}\text { Grahamdale Site } \\
7 \\
\text { (preferred site } \\
\text { chosen by } \\
\text { community) }\end{array}$ & $\begin{array}{l}\text { Kiesman/ } \\
\text { Lowry }\end{array}$ & $\begin{array}{l}\text { Kapyong } \\
\text { Barracks }\end{array}$ & $\begin{array}{l}\text { Swan } \\
\text { Lake }\end{array}$ \\
\hline \multicolumn{8}{|l|}{ Political } \\
\hline - $\quad$ Interim site & $\mathrm{Y}$ & $\mathrm{Y}$ & $\mathrm{Y}$ & $Y$ & $\mathrm{Y}$ & $\mathrm{Y}$ & $\mathrm{Y}$ \\
\hline $\begin{array}{ll}- & \text { Permanent } \\
& \text { community }\end{array}$ & $\mathrm{N}$ & $\mathrm{N}$ & $\mathrm{N}$ & Y & Y & $\mathrm{N}$ & $\mathrm{N}$ \\
\hline - $\quad$ Band office facilities & $\mathrm{N}$ & $\mathrm{N}$ & $\mathrm{N}$ & Y & Y & $\mathrm{N}$ & $\mathrm{N}$ \\
\hline $\begin{array}{ll}\text { Supports Good } \\
\text { Governance }\end{array}$ & $\mathrm{N}$ & $\mathrm{N}$ & $\mathrm{N}$ & $\mathrm{Y}$ & $\mathrm{Y}$ & $\mathrm{N}$ & $\mathrm{N}$ \\
\hline $\begin{array}{ll}\text { - } & \text { Impact on } \\
\text { Remedying } 3^{\text {rd }} \text { vs } 1 \text { st } \\
\text { party management }\end{array}$ & $\mathrm{N}$ & $\mathrm{N}$ & $\mathrm{N}$ & Y & Y & $\mathrm{N}$ & $\mathrm{N}$ \\
\hline \multicolumn{8}{|l|}{ Environment } \\
\hline - $\quad$ Hunting & $\mathrm{N}$ & $\mathrm{N}$ & $\mathrm{N}$ & $\mathrm{Y}$ & $\mathrm{Y}$ & $\mathrm{N}$ & $\mathrm{N}$ \\
\hline - $\quad$ Fishing & $\mathrm{N}$ & $\mathrm{N}$ & $\mathrm{N}$ & $\mathrm{N}$ & $\mathrm{N}$ & $\mathrm{N}$ & $\mathrm{N}$ \\
\hline - $\quad$ Forest & $\mathrm{N}$ & $\mathrm{N}$ & $\mathrm{N}$ & $\mathrm{Y}$ & $\mathrm{Y}$ & $\mathrm{N}$ & $\mathrm{N}$ \\
\hline - Cleared land & $P$ & $\mathrm{Y}$ & $\mathrm{Y}$ & $P$ & $\mathrm{P} / \mathrm{N}$ & $\mathrm{Y}$ & $\mathrm{Y}$ \\
\hline - Good drinking water & $\begin{array}{l}\mathrm{N} \text { (water } \\
\text { tracked to } \\
\text { cisterns) }\end{array}$ & $\mathrm{N}$ & $\mathrm{N}$ & WELL & WELL & $\mathrm{Y}$ & $Y$ \\
\hline $\begin{array}{l}\text { - Access to surface } \\
\text { water }\end{array}$ & $\mathrm{N}$ & $\mathrm{N}$ & $\mathrm{N}$ & $Y$ & $\mathrm{~N}$ & $\mathrm{~N}$ & $\mathrm{~N}$ \\
\hline $\begin{array}{l}\text { Wildlife co- } \\
\text { management }\end{array}$ & $\mathrm{N}$ & $\mathrm{N}$ & $\mathrm{N}$ & $\mathrm{Y}$ & $\mathrm{Y}$ & $\mathrm{N}$ & $\mathrm{N}$ \\
\hline $\begin{array}{l}\text { Walkable community } \\
\text { from central facilities } \\
\text { to homes }\end{array}$ & & & & & & & \\
\hline $\begin{array}{l}\text { Paved rather than } \\
\text { gravel roads }\end{array}$ & & & & & & & \\
\hline \multicolumn{8}{|l|}{ Social } \\
\hline $\begin{array}{l}\text { - Recreational spaces } \\
\text { and facilities }\end{array}$ & $\mathrm{N}$ & $P$ & $P$ & $Y$ & $Y$ & $\mathrm{Y}$ & $\mathrm{N}$ \\
\hline $\begin{array}{ll}\text { Gender } \\
\text { consideration }\end{array}$ & $\mathrm{N}$ & $\mathrm{N}$ & $\mathrm{N}$ & TBP & TBP & $\mathrm{N}$ & $\mathrm{N}$ \\
\hline $\begin{array}{l}\text { Facilities to deal with } \\
\text { trauma of } \\
\text { displacement }\end{array}$ & $\mathrm{Y}$ & $Y$ & $\mathrm{Y}$ & $Y$ & $\mathrm{Y}$ & $\mathrm{Y}$ & $\bar{Y}$ \\
\hline $\begin{array}{l}\text { Church/spiritual/ } \\
\text { place of worship }\end{array}$ & $\mathrm{N}$ & $\mathrm{N}$ & $\mathrm{N}$ & TBP & TBP & $\mathrm{N}$ & $\mathrm{N}$ \\
\hline $\begin{array}{l}\text { Adequate cooking } \\
\text { facilities and } \\
\text { restaurants }\end{array}$ & $\mathrm{N}$ & $\mathrm{N}$ & $\mathrm{N}$ & TBP & TBP & $\mathrm{Y}$ & $\mathrm{N}$ \\
\hline
\end{tabular}


Ballard \& Thompson (2013)

\begin{tabular}{|c|c|c|c|c|c|c|c|}
\hline Social cont'd & $\begin{array}{l}\text { Pinemuta } \\
\text { Radar base } \\
\text { (interim site) }\end{array}$ & Halaburda & Rohl & $\begin{array}{l}\text { Grahamdale Site } \\
7 \\
\text { (preferred site } \\
\text { chosen by } \\
\text { community) }\end{array}$ & $\begin{array}{l}\text { Kiesman/ } \\
\text { Lowry }\end{array}$ & $\begin{array}{l}\text { Kapyong } \\
\text { Barracks }\end{array}$ & $\begin{array}{l}\text { Swan } \\
\text { Lake }\end{array}$ \\
\hline - Healthy housing & $M$ & $M$ & $M$ & $M$ & $M$ & $\bar{Y}$ & $\bar{N}$ \\
\hline - $\quad$ Daycare facilities & TBP & TBP & TBP & TBP & TBP & - & - \\
\hline $\begin{array}{ll}\text { - } & \text { Anishinaabe } \\
\text { - } & \text { Language focus }\end{array}$ & TBP & TBP & TBP & TBP & TBP & $\mathrm{N}$ & $\mathrm{N}$ \\
\hline $\begin{array}{l}\text { School with gym } \\
\text { and food services } \\
\text { (K-12) }\end{array}$ & $\mathrm{N}$ & $\mathrm{N}$ & $\mathrm{N}$ & TBP & TBP & $\mathrm{N}$ & $\mathrm{N}$ \\
\hline $\begin{array}{l}\text { - Health/nursing } \\
\text { facilities }\end{array}$ & $\mathrm{T}$ & $\mathrm{N}$ & $\mathrm{N}$ & TBP & TBP & $\mathrm{N}$ & $\mathrm{N}$ \\
\hline $\begin{array}{l}\text { Wheel chair access } \\
\text { in Elder facilities }\end{array}$ & $\mathrm{N}$ & $\mathrm{N}$ & $\mathrm{N}$ & TBP & TBP & $\mathrm{N}$ & $\mathrm{N}$ \\
\hline $\begin{array}{ll}\text { - } & \text { Recreational } \\
\text { facilities }\end{array}$ & $\mathrm{N}$ & $\mathrm{N}$ & $\mathrm{N}$ & TBP & TBP & $\mathrm{N}$ & $\mathrm{N}$ \\
\hline $\begin{array}{ll}\text { - } & \text { Youth recreation } \\
\text { Facilities }\end{array}$ & $\mathrm{N}$ & $\mathrm{N}$ & $\mathrm{N}$ & TBP & TBP & $\mathrm{N}$ & $\mathrm{N}$ \\
\hline - Library & $\mathrm{N}$ & $\mathrm{N}$ & $\mathrm{N}$ & TBP & TBP & $\mathrm{N}$ & $\bar{N}$ \\
\hline \multicolumn{8}{|l|}{ Health issues } \\
\hline 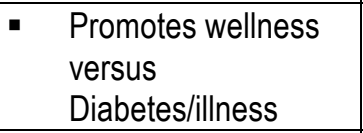 & $\mathrm{N}$ & $\mathrm{N}$ & $\mathrm{N}$ & TBP & TBP & $\mathrm{N}$ & $\mathrm{N}$ \\
\hline $\begin{array}{l}\text { Disability or } \\
\text { wheelchair access }\end{array}$ & $\mathrm{N}$ & $\mathrm{N}$ & $\mathrm{N}$ & TBP & TBP & $\mathrm{N}$ & $\mathrm{N}$ \\
\hline $\begin{array}{l}\text { Addresses Social } \\
\text { determinants of } \\
\text { health (e.g., poverty, } \\
\text { etc) }\end{array}$ & $\mathrm{N}$ & $\mathrm{N}$ & $\mathrm{N}$ & TBP & TBP & $\mathrm{N}$ & $\mathrm{N}$ \\
\hline $\begin{array}{l}\text { Addresses Chronic } \\
\text { disease prevention }\end{array}$ & $\mathrm{N}$ & $\bar{N}$ & $\mathrm{~N}$ & TBP & TBP & $\mathrm{N}$ & $\mathrm{N}$ \\
\hline $\begin{array}{l}\text { Assisted living } \\
\text { facilities for elders }\end{array}$ & $\mathrm{N}$ & $\mathrm{N}$ & $\mathrm{N}$ & TBP & TBP & $\mathrm{N}$ & $\mathrm{N}$ \\
\hline \multicolumn{8}{|l|}{ Cultural } \\
\hline $\begin{array}{l}\text { Access to traditional } \\
\text { medicines }\end{array}$ & $\mathrm{N}$ & $\mathrm{N}$ & $\mathrm{N}$ & $\mathrm{Y}$ & $\bar{Y}$ & $\mathrm{~N}$ & $\bar{N}$ \\
\hline $\begin{array}{l}\text { - Places and soil to } \\
\text { Garden }\end{array}$ & $\mathrm{N}$ & $\bar{Y}$ & $\mathrm{Y}$ & $\mathrm{Y}$ & $\mathrm{Y}$ & $\mathrm{N}$ & $\mathrm{N}$ \\
\hline - Language facility & $\mathrm{N}$ & $\mathrm{N}$ & $\mathrm{N}$ & TBP & TBP & $\mathrm{N}$ & $\mathrm{N}$ \\
\hline - Language classes & $\mathrm{N}$ & $\mathrm{N}$ & $\mathrm{N}$ & TBP & TBP & $\mathrm{N}$ & $\mathrm{N}$ \\
\hline $\begin{array}{l}\text { Elders meeting } \\
\text { space }\end{array}$ & $\mathrm{N}$ & $\mathrm{N}$ & $\mathrm{N}$ & $\mathrm{N}$ & $\mathrm{N}$ & $\mathrm{N}$ & $\mathrm{N}$ \\
\hline - $\quad$ Traditional Land use & $\mathrm{N}$ & $\mathrm{N}$ & $\mathrm{N}$ & $\mathrm{Y}$ & $\bar{Y}$ & $\mathrm{~N}$ & $\mathrm{~N}$ \\
\hline $\begin{array}{ll}\text { Cultural gathering } \\
\text { space/grounds }\end{array}$ & $\mathrm{N}$ & $\mathrm{N}$ & $\mathrm{N}$ & $\mathrm{Y}$ & $\mathrm{Y}$ & $\mathrm{N}$ & $\mathrm{N}$ \\
\hline - Cultural facility & $\mathrm{N}$ & $\mathrm{N}$ & $\mathrm{N}$ & $\mathrm{Y}$ & $\mathrm{Y}$ & $\mathrm{N}$ & $\mathrm{N}$ \\
\hline - Hunting & $\mathrm{N}$ & $\mathrm{N}$ & $\mathrm{N}$ & $\mathrm{Y}$ & $\mathrm{Y}$ & $\mathrm{N}$ & $\mathrm{N}$ \\
\hline
\end{tabular}


Ballard \& Thompson (2013)

\begin{tabular}{|c|c|c|c|c|c|c|c|}
\hline Economic & $\begin{array}{l}\text { Pinemuta } \\
\text { Radar base } \\
\text { (interim site) }\end{array}$ & Halaburda & Rohl & $\begin{array}{l}\text { Grahamdale Site } \\
7 \\
\text { (preferred site } \\
\text { chosen by } \\
\text { community) }\end{array}$ & $\begin{array}{l}\text { Kiesman/ } \\
\text { Lowry }\end{array}$ & $\begin{array}{l}\text { Kapyong } \\
\text { Barracks }\end{array}$ & $\begin{array}{l}\text { Swan } \\
\text { Lake }\end{array}$ \\
\hline - $\quad$ Ecotourism & & & & & & & \\
\hline - $\quad$ Commercial Fishing & $\mathrm{N}$ & $\mathrm{N}$ & $\mathrm{N}$ & $\mathrm{N} / \mathrm{Y}$ & $\mathrm{N} / \mathrm{Y}$ & $\mathrm{N}$ & $\mathrm{N}$ \\
\hline - $\quad$ Seneca root digging & $\mathrm{N}$ & $\mathrm{N}$ & $\mathrm{N}$ & $\mathrm{Y}$ & $\mathrm{Y}$ & $\mathrm{N}$ & $\mathrm{N}$ \\
\hline - Close to highway & $\mathrm{Y}$ & $\mathrm{N}$ & $\mathrm{N}$ & $\mathrm{Y}$ & $\mathrm{Y}$ & $\mathrm{Y}$ & $\mathrm{Y}$ \\
\hline - $\quad$ Paved road & $\mathrm{Y}$ & $\mathrm{N}$ & $\mathrm{N}$ & TBP & TBP & $\mathrm{Y}$ & $\mathrm{Y}$ \\
\hline - $\quad$ Paved driveways & $\mathrm{Y}$ & $\mathrm{N}$ & $\mathrm{N}$ & TBP & TBP & $\mathrm{Y}$ & $\mathrm{N}$ \\
\hline $\begin{array}{ll}\text { - } & \text { Alternative Energy } \\
\text { - } & \text { Biomass/geotherma }\end{array}$ & $\mathrm{N}$ & $\mathrm{N}$ & $\mathrm{N}$ & TBP & TBP & $\mathrm{N}$ & $\mathrm{N}$ \\
\hline - $\quad$ Lagoon & $Y$ & $\mathrm{~N}$ & $\mathrm{~N}$ & TBP & TBP & $Y$ & $\mathrm{~N}$ \\
\hline - Waste disposal site & $\mathrm{Y}$ & $\mathrm{N}$ & $\mathrm{N}$ & TBP & TBP & $\mathrm{Y}$ & $Y$ \\
\hline $\begin{array}{l}\text { Sewer system } \\
\text { (inground and piped } \\
\text { with treatment plant } \\
\text { - level } 2 \text { not just } \\
\text { lagoon) }\end{array}$ & $\mathrm{N}$ & $\mathrm{N}$ & $\mathrm{N}$ & TBP & TBP & $\mathrm{Y}$ & $\bar{N}$ \\
\hline - Healthy food access & $\mathrm{N}$ & $\mathrm{N}$ & $\mathrm{N}$ & $Y$ & $\bar{Y}$ & $\bar{Y}$ & $Y$ \\
\hline $\begin{array}{ll}\text { - } & \text { Piped water to all } \\
& \text { houses and facilities }\end{array}$ & & & & & & & \\
\hline $\begin{array}{l}\text { Ability to develop } \\
\text { supermarket }\end{array}$ & $\mathrm{N}$ & $\mathrm{N}$ & $\mathrm{N}$ & $\bar{Y}$ & $\bar{Y}$ & $\mathrm{~N}$ & $\mathrm{~N}$ \\
\hline - $\quad$ Market activities & $\mathrm{N}$ & $\mathrm{N}$ & $\mathrm{N}$ & $Y$ & $Y$ & $\mathrm{Y}$ & $Y$ \\
\hline - $\quad$ Casino Potential & $\mathrm{N}$ & $\mathrm{N}$ & $\mathrm{N}$ & $\mathrm{Y}$ & $\mathrm{Y}$ & $\mathrm{N}$ & $\mathrm{N}$ \\
\hline - Gas bar & $\mathrm{N}$ & $\mathrm{N}$ & $\mathrm{N}$ & $\bar{Y}$ & $\bar{Y}$ & $\mathrm{~N}$ & $\mathrm{~N}$ \\
\hline - $\quad$ Restaurant & $\mathrm{N}$ & $\mathrm{N}$ & $\mathrm{N}$ & $\bar{Y}$ & $\bar{Y}$ & $\mathrm{~N}$ & $\mathrm{~N}$ \\
\hline - $\quad$ Ranching & $\mathrm{N}$ & $\mathrm{Y}$ & $Y$ & $Y$ & $\mathrm{Y}$ & $\mathrm{N}$ & $\mathrm{N}$ \\
\hline - $\quad$ Cattle farming & $\mathrm{N}$ & $\mathrm{N}$ & $\mathrm{N}$ & $Y$ & $\mathrm{Y}$ & $\mathrm{N}$ & $\mathrm{N}$ \\
\hline - $\quad$ Dairy farming & $\mathrm{N}$ & $\mathrm{N}$ & $\mathrm{N}$ & $Y$ & $Y$ & $\mathrm{~N}$ & $\mathrm{~N}$ \\
\hline - $\quad$ Other livestock & $\mathrm{N}$ & $\mathrm{N}$ & $\mathrm{N}$ & $\bar{Y}$ & $\bar{Y}$ & $\mathrm{~N}$ & $\mathrm{~N}$ \\
\hline $\begin{array}{l}\text { - Grains and } \\
\text { vegetable farming }\end{array}$ & $\mathrm{N}$ & $Y$ & $Y$ & $Y$ & $\mathrm{Y}$ & $\mathrm{N}$ & $\mathrm{N}$ \\
\hline $\begin{array}{l}\text { - Subsistence } \\
\text { activities }\end{array}$ & $\mathrm{N}$ & $\mathrm{N}$ & $\mathrm{N}$ & $Y$ & $Y$ & $\mathrm{~N}$ & $\mathrm{~N}$ \\
\hline - $\quad$ Recreation & $\mathrm{N}$ & $\mathrm{N}$ & $\mathrm{N}$ & $Y$ & $\bar{Y}$ & $\mathrm{~N}$ & $\mathrm{~N}$ \\
\hline $\begin{array}{ll}- & \text { Adequate } \\
& \text { Infrastructure } \\
\end{array}$ & $P$ & $\mathrm{~N}$ & $\mathrm{~N}$ & $\mathrm{~N}$ & $\bar{Y}$ & $Y$ & $\mathrm{Y}$ \\
\hline $\begin{array}{ll} & \text { Central office } \\
\text { complex/mall }\end{array}$ & $\mathrm{N}$ & $\mathrm{N}$ & $\mathrm{N}$ & TBP & TBP & $\mathrm{N}$ & $\mathrm{N}$ \\
\hline - $\quad$ Conference facility & $\mathrm{N}$ & $\mathrm{N}$ & $\mathrm{N}$ & TBP & TBP & $\mathrm{N}$ & $\mathrm{N}$ \\
\hline - $\quad$ Arena & $\mathrm{N}$ & $\mathrm{N}$ & $\mathrm{N}$ & TBP & TBP & $\mathrm{N}$ & $\mathrm{N}$ \\
\hline
\end{tabular}

Notes: $\mathrm{Y}=$ Yes; $\mathrm{N}=$ No; $\mathrm{M}=$ Modular; $\mathrm{P}=$ Partial; $\mathrm{TBP}=$ To be planned - recognizing that a site no planning for long term sustainability is possible; $\mathrm{T}=$ Temporary 


\section{Ballard \& Thompson (2013)}

\section{Findings}

Sustainable livelihood capitals

The authors of this article wrote a resolution for the SCO (passed in 2012) that highlighted the findings of this research. Many of the impacts to sustainable livelihoods are listed, particularly regarding social, environmental, and physical impacts. The resolution, in part, reads:

Whereas: Social impacts from the stress of displacement from the 2011 flood included attempted and actual suicides, family break-ups, increased family violence, drug use, alcoholism, and recruitment of community members by gangs in urban centres and host communities ...

Whereas: Impacts of the flooding on the health of the community members has resulted in miscarriages, depression, other mental health symptoms, difficulties addressing those who have a chronic disease, etc., and have resulted in premature deaths ...

Whereas: Environmental impacts of the flood include water saturated land that does not support forests or agriculture; unsafe drinking water contaminated from waste and wastewater lagoons, toxic impacts from landfill, destruction of fisheries, ecosystem and habitat; and,

Whereas: Physical impacts on infrastructure include housing deterioration due to mould and chronic dampness, roads degradation, unsafe drinking water, destruction of schools, a loss of churches and other public buildings. Resettlement of community members of some reserves is needed to pursue the development of a community base capable of economic development opportunities to ensure basic needs for safe drinking water, healthy and sufficient housing, ... food security and capacity building .... . (SCO, 2012)

After detailing these impacts, there was a call for action for community planning in the last part of the resolution:

Community planning that is culturally appropriate and community-driven is required to ensure resettlement incorporates healthy and culturally appropriate and adequate housing, adequate and sustainable infrastructure, an economic base, access to healthy affordable and traditional foods for food security and safe drinking water. (SCO, 2012)

This is in acknowledgement that:

There is no needs assessment or comprehensive community plan for any flood impacted community that considers cultural integrity, healthy living, and natural resources (water, forest, solar, wind, geothermal, agriculture, and country foods) and economic development for sustainability. (SCO, 2012)

\section{Site analysis}

To determine community priorities for a new site for Lake St. Martin FN a number of participatory workshops provided feedback. Community youth and elders provided input into the community plan for development and the priorities in Table 1 based on the five PESCE criteria. 


\section{Ballard \& Thompson (2013)}

Political Assets

Institutional structures (e.g., rules, customs, and land tenure) and processes (e.g., laws, policies, societal norms, and incentives) operate at multiple levels (provincial government, federal government, multinational corporations) on Lake St. Martin FN community (Carney, 1998; Ellis, 2000; Scoones, 1998; Thompson, Kamal, Alam, and Wiebe, 2012). The Indian Act and colonial policies that continue to this day take away local decisionmaking and increase the vulnerability of FN communities (Ballard, 2012; Thompson et al, 2012). Accounting firms put in place by Aboriginal Affairs and Northern Development Canada, control communities' funding and management (Ballard, 2012). Money that would normally go to programs and the Anishinabek, pay salaries to the third party managers in Winnipeg.

Institutional structures and processes worked against Lake St. Martin FN interests again and again. Colonial structures meant that the FN had no power to control the water levels. The same applies to their interim community -the community had no power to influence the results of where the community would be relocated. The Province chose to flood and temporarily relocate the community to an abandoned military base against their wishes and despite the community democratically voting for an immediate permanent site with economic, cultural, and environmental potential. The two parcels of land selected by the community were inexpensive at $\$ 79,000$ and $\$ 1$ million, which was much cheaper than the $\$ 14$ million payout received by the Province through the Disaster Financial Assistance Arrangement (DFAA) Fund for the interim development of the military base. Clearly, this permanent site would have saved money. Then, the Province unilaterally decided to put a $\$ 100$ million water channel adjacent to the flooded Lake St. Martin FN without consulting the community, and with the objection of the community.

\section{Economic Assets}

The people of Lake St. Martin FN lost their ancestral lands and their sustainable livelihood based on fishing, farming, and hunting due to the flood and their subsequent relocation, without sufficient compensation. Destruction of the fisheries, vital to the Lake St. Martin FN, resulted in local fishermen losing their commercial licenses-receiving only $\$ 5000$ compensation each. These fishermen cannot survive on this low level of compensation.

Each family lost their home, and although not titled to them, the homes were in some cases in the family for generations. These same families were left with no more than a few suitcases, which they had to shuffle from one hotel to another. Almost all of their furnishings and personal effects were destroyed as community members were told by authorities not to take them-and were not provided with any storage facilities.

The Winnipeg Humane society played an interesting role. The Winnipeg Humane Society is a "registered charity dedicated to protecting animals from suffering and to promoting their welfare and dignity". This Humane Society provided much appreciated assistance by rescuing dearly loved pets from the community after the evacuation. However, pictures of the pets were put on their website advising evacuees to pick up their pets, which was inconsiderate and to some degree slanderous (Beeston, 2011; Winnipeg Humane Society, 2012). In their newsletter, they reference the plight of the dogs but not the people: "the plight of the Lake St. Martin dogs ... spearheaded the food drive for the dogs ... and removing nearly 300 dogs from flood-affected communities, nearly 160 of these were Lake St. Martin First Nation." The article in the Winnipeg Free Press (Beeston, 2011) shows a dog that was shot and seems to blame inhumane community members with the Winnipeg Humane Society CEO Bill McDonald stating: "Leaving your dogs behind (in a flood) is not standard practice ... . At the end of the day, reserve dogs are owned and not-owned," explaining many roam free on the Reserve (Beeston, 2011). How could evacuees living in hotels, where pets were not allowed, pick up their pets? This added to the distress among children and families and further turned the public against the flood victims. Their "humane"- 


\section{Ballard \& Thompson (2013)}

ness seemed to extend only to animals and not to the people. They seemed to condemn the flood victims in the article. Although animals impacted by the flood were protected-nobody protected the flood victims from suffering, and nobody promoted their welfare and dignity.

As FN members' homes and land are owned by the Crown and not the inhabitants, compensation for the houses never materialized (Ballard, 2012). Without collateral, FN peoples have limited ability to obtain credit to build new enterprises. The houses, churches, schools, and almost all buildings were destroyed by mould and chronic dampness, and cannot be rebuilt without compensation. For example, a 78-year-old grandmother, and lifetime resident on the Reserve, lost her family home that she had renovated using her own money, to include a porch and a garage, but received a letter from the Provinces' Emergency Measures Organization (EMO) stating she was ineligible for compensation. Other people received similar letters stating they were ineligible for compensation, despite losing everything (Figure 4: Letter from Manitoba EMO).

Figure 4: Letter from Manitoba EMO

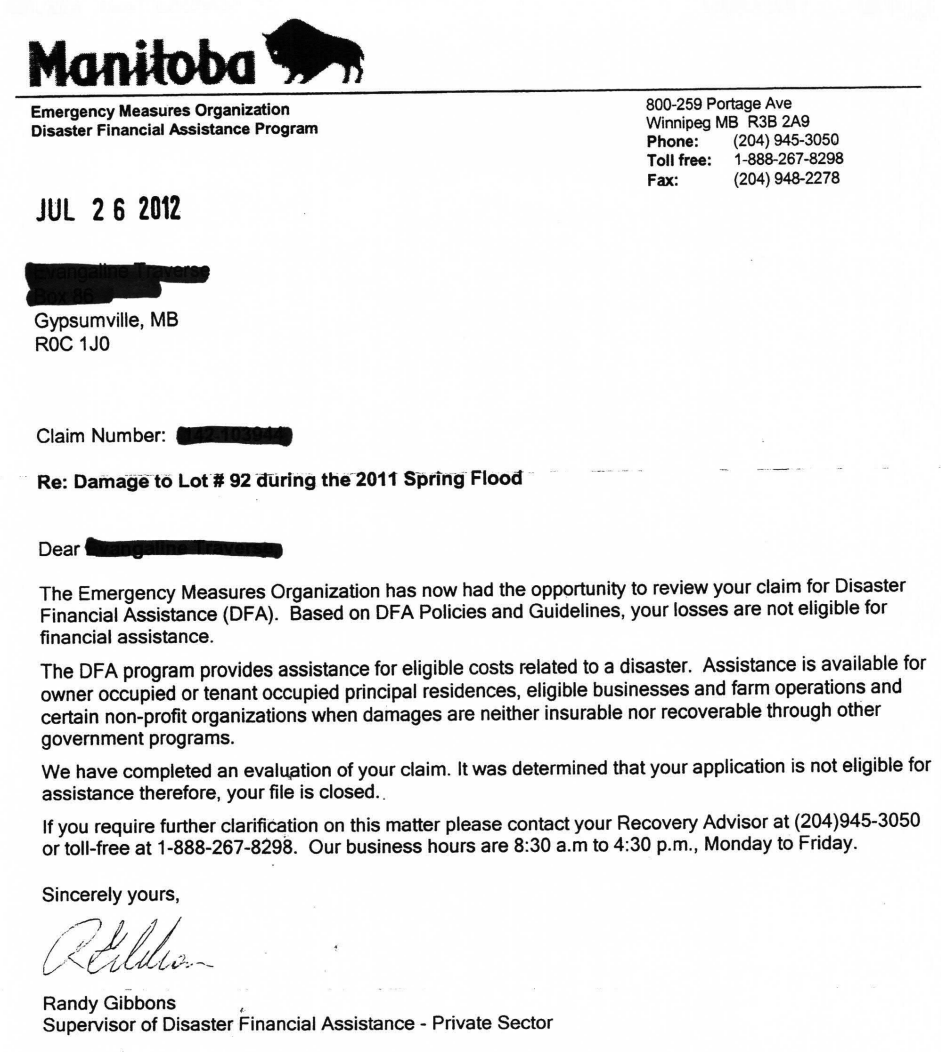


Social Assets

Social capital or assets (the close social bonds that facilitates cooperative action, social bridging, and linking to share and access ideas and resources), once strong, have been weakened by separation and the negative media against Lake St. Martin FN members. Lake St. Martin FN members had little influence over policies, programs, or development (Ballard, 2012; Thompson et al, 2011c). No charities, NGOs, or development agencies rose up to assist the FN as they struggled with the impacts of the flood (Ballard, 2012; Ballard et al, 2012). Assembly of Manitoba Chiefs, Assembly of First Nations, and SCO were supportive and provided media releases but lacked capacity or funding to provide more tangible supports.

Social and health impacts from the stress of displacement from the 2011 flood include attempted and actual suicides, sudden deaths, family-breakups, increased family violence, drug-use, alcoholism, and recruitment of community members by gangs in urban centres and host communities (Ballard et al, 2012; SCO, 2012). Reported impacts of the flood on the health of community members included miscarriages, depression, other mental health symptoms, and premature deaths from chronic diseases. The many elders who died prematurely could not be buried in their home communities due to high water tables.

The people of Lake St. Martin FN continue to suffer from deep trauma, with high stress and anxiety reported by community members. According to the World Health Organization(WHO), mental health issues result from flooding and displacement: "floods take a heavy toll on the mental health of the people involved" (WHO, 2001, p. 43). Evidence points to mental disorders (anxiety, depression), posttraumatic stress syndrome, and suicide (WHO, 2001; Ahern, Kovats, Wilkinson, Few, and Matthies, 2004) as possible outcomes of flooding and displacement. People feel that they can no longer fulfill their assigned roles in life, vision, and purpose of why they were created. With so little hope, depression and suicide result. Elders, confined to the small space of a hotel room, reported being so depressed they could not get out of bed (Ballard, 2012). The nurse for Lake St. Martin FN noted seeing many signs of chronic depression, which can result in self-destructive behaviour. The children, when asked to draw their pictures of impacts, showed their community under water and stated how sad they were from missing their home and community (see Figure 5).

Figure 5: Children's drawing about missing their community

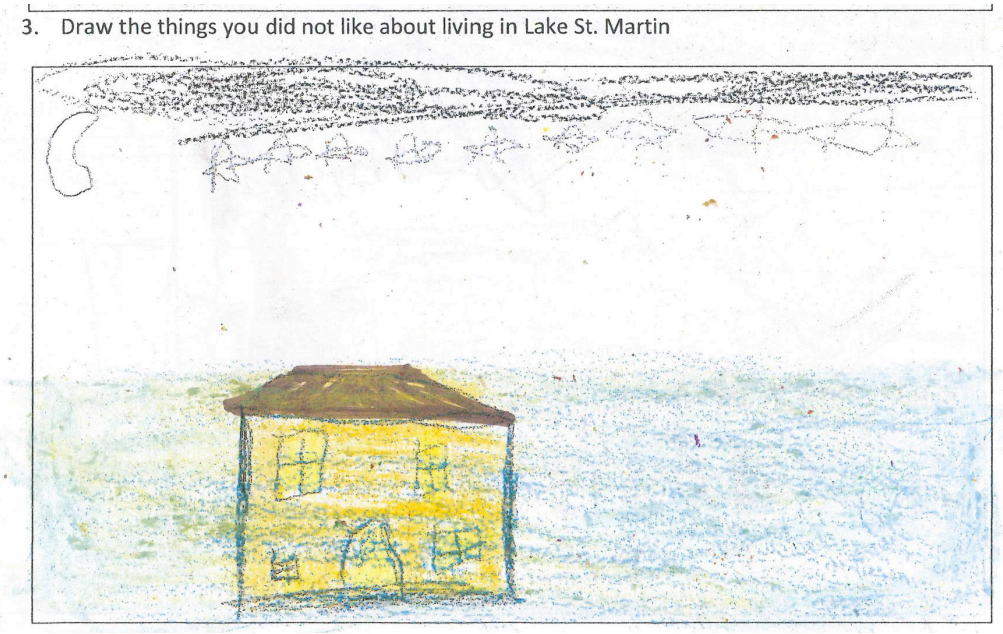




\section{Ballard \& Thompson (2013)}

Cultural Assets

Spirituality was an important part of life for Lake St. Martin FN community members. Spiritual activities are missed, particularly the gatherings, which were a form of spiritual retreat, visiting, and fellowship. Community members stated in interviews that they miss the gathering activities: during the summer months, the communities had outdoor spiritual gatherings for weeks at a time, which were followed by feasts. Visiting each other is an important part of native culture, but now people are so dispersed that they have lost track of each other. This dispersal has also meant that people are not able to visit and communicate in their Anishinaabe language. Moreover, deaths are spiritual events in Lake St Martin FN where the whole community mourns for many days. The Lake St. Martin FN members have not been able to have wake services in their community, although there have been many deaths since the evacuation, many of them sudden and violent. Wake services are part of native culture and it has been difficult to say goodbye to loved ones and it is impossible to bury people in saturated ground. A 2012 article by Galloway in the Globe and Mail mentions an elder who lost her fight to cancer. Instead of spending her final days and dying in her community, she died "nearly 300 kilometers to the south - on the $23^{\text {rd }}$ floor of a hotel near Portage and Main" (Galloway, 2012, p. F1).

\section{Environmental assets}

Environmental assets include both natural capital (resources and land management) and physical capital (equipment and infrastructure). Natural capital in fisheries, forests, minerals, and non-timber products in the Lake St. Martin FN's territory is abundant but they have no regulatory or ownership rights to their territory's resources (Ballard, 2012; LaDuke, 2002; Thompson et al, 2011c). The lake has flooded and spilled over the waste and wastewater lagoons and waste dump contaminating both the groundwater and the lake. The fisheries, ecosystem, and habitat has been destroyed and contaminated. All infrastructure, including roads, has since been decimated by flooding. Resettlement of community members is needed to enable the development of a community base capable of sustaining economic development opportunities and the basic need for safe drinking water, healthy and sufficient housing, health, food security, and capacity building.

Water-saturated land no longer support forests or agriculture. The beautiful community lined with beaches and lakes to swim in is now a wasteland. The community once held annual baseball tournaments and boasted several baseball teams and three baseball diamonds. Now these geographically dispersed people seldom physically get together for community gatherings.

\section{PESCE overall analysis}

Most relocation sites chosen by the Province did not fare well because they offered no hope for permanent settlement due to their lack of pimachiwiin. The radar base was the worst of the seven options due to this lack of pimachiwiin: e.g. an absence of good drinking water, lakes for fishing, and land to grow food. The radar base lacked any facilities to build a community including places for worship, schools, or elders' facilities. Culturally and economically, the site offered no possibilities. Despite the fact that the people spoke against the radar base, the provincial government developed the base and tried moving Lake St. Martin FN members. Community members refused due to the rigid Manitoba Housing tenancy agreements and the lack of pimachiwiin. By the spring of 2013 , only 13 of the approximate 60 homes were occupied. In this temporary community, infrastructure such as church or school were never offered or part of the provincial plan

The planning of the temporary community did not consider any cultural elements. For example, grandparents, who wanted bigger two- and three-bedroom units because their grandchildren live with them, were denied these units without legal guardianship documents. These elders were forced to live in one-bedroom row housing, 


\section{Ballard \& Thompson (2013)}

which disrespects FN's culture where grandparents look after their grandchildren, and continue living with them, until they are teens and adults with the blessing and assistance of the parents. Much pressure and lobbying continues with the Province to change its policies to allow grandchildren to live with their grandparents.

The most favourable location, according to community members, was considered to be the Grahamdale Site. This site was the only location Lake St. Martin FN wanted as a permanent site. Lake St. Martin FN developed a plan for the sustainable development (an "eco-reserve" model community) of the Grahamdale Site during workshops. Community members planned a walkable and self-sufficient community with local renewable energy, food, and water resources. The community wanted infrastructure and services, generally not available on FNs, but commonly available elsewhere, including a fire station, laundromat, grocery store, and daycare, but also cultural facilities.

The children planned their new home community with a school, church, and houses around a lake with paved roads. One showed music coming from homes, schools, and churches (see Figures 6 and 7 ). Many children drew two story homes and all drew paved roads, probably due to the dust, mud, and nuisance that gravel roads cause. Paved roads are rare in Manitoba FN reserves but standard in non-First Nation communities.

\section{Figure 6: Children's drawing about their community}

2. Draw the best things about living in Lake st. Martin.

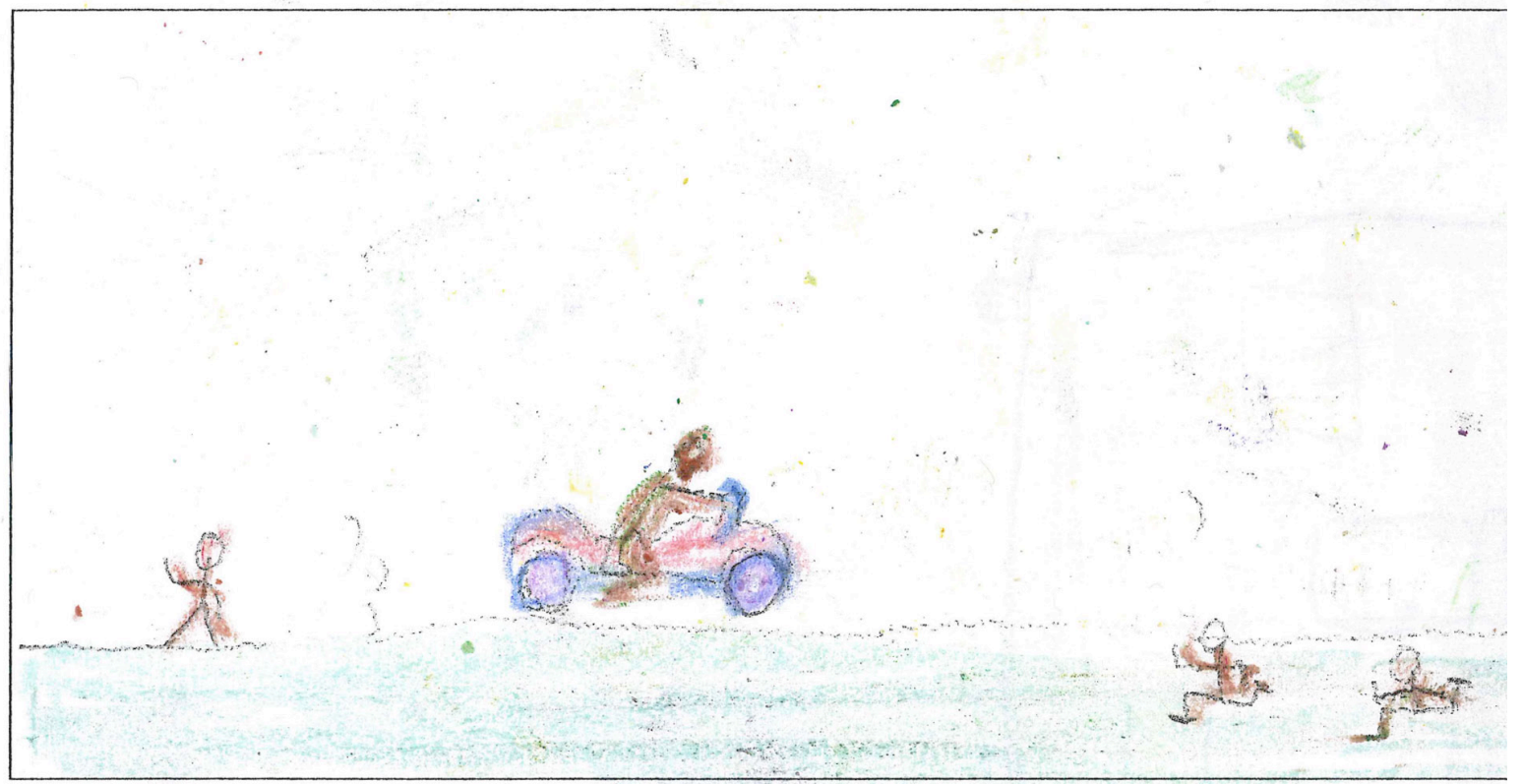




\section{Ballard \& Thompson (2013)}

Figure 7: Children's drawing about their community

4. Draw what you want the new community of Lake St. Martin First Nation to look like in the box below.

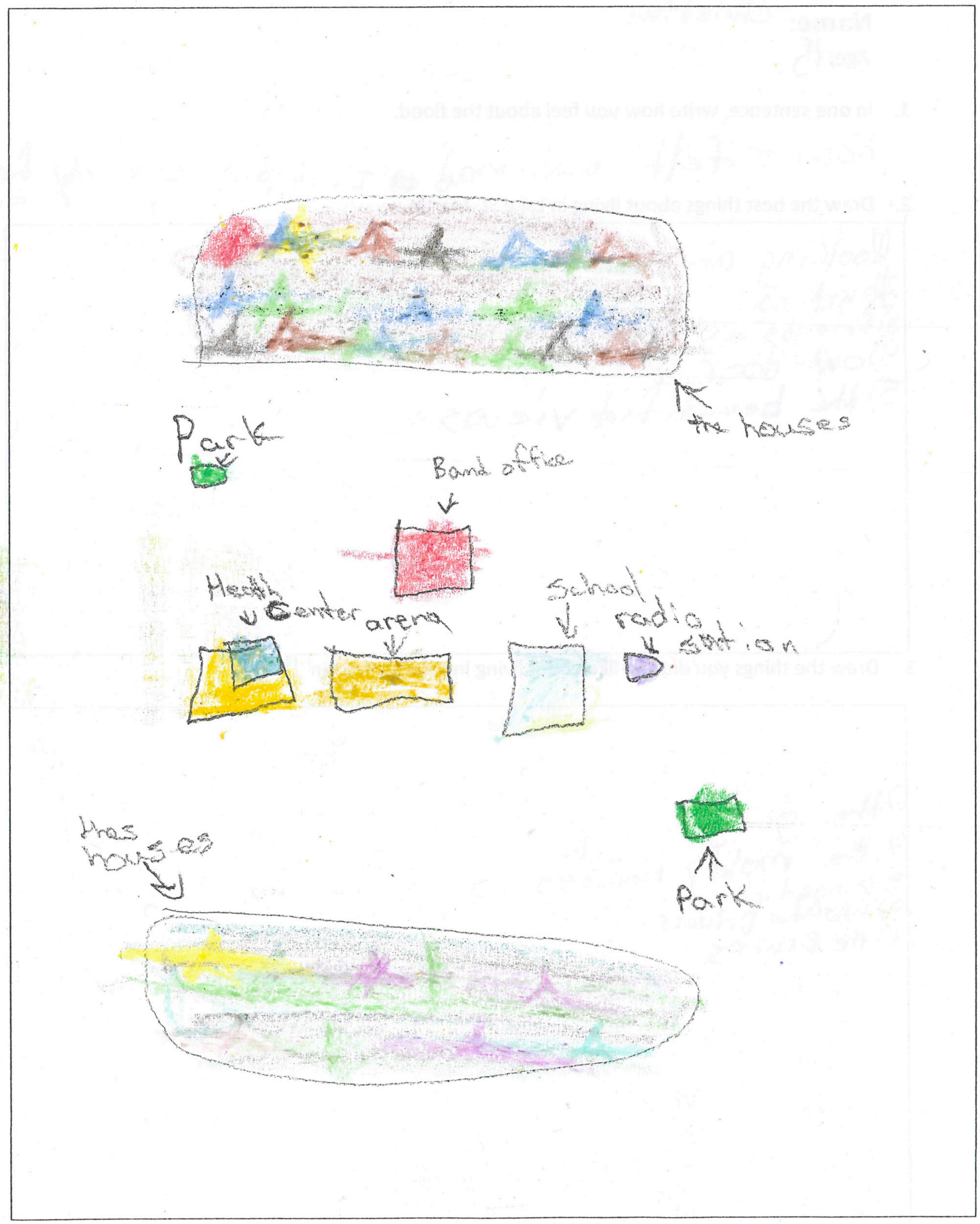




\section{Ballard \& Thompson (2013)}

\section{CONCLUSION}

The "superflood" of 2011 heading towards Winnipeg was diverted towards Lake St. Martin FN. The entire community was permanently displaced from their homes, losing their livelihoods, health, and socio-cultural integrity. The provincial government used the Fairford water control structure to flood people with a deep history to the land, compared to cottagers and farmers, who had an economic and recreational interest.

The flood caused great distress and trauma to people, but so did the way the Province dealt with it. The Province, after flooding the people of Lake St. Martin FN out of their ancestral home, has left them homeless by selecting an old military base as an interim camp -a site that lacks infrastructure and that community members call an internment camp. People refuse to live there and most houses remain empty. The PESCE analysis clearly shows that this site lacks pimachiwiin, or the capacity to look after the next seven generations. The people prioritize their need for access to water, food, and land, for pimachiwiin, for future generations of Anishinabek, and socio-cultural integrity. The community wants an "eco-reserve" that is sustainable and walkable, and control over their future.

Lake St. Martin FN aspires to be healthy, sustainable, walkable community, but the land and plan the community voted for was undermined by the actions of the Province. The lack of control over their future has taken a heavy toll on community members. Ultimately, the community decision on a permanent site, and plan to meet the community's cultural priorities, was overpowered, leaving them nowhere.

\section{ACKNOWLEDGEMENTS}

The authors would like to thank the Lake St. Martin First Nation evacuees for their contribution toward this research.

\section{REFERENCES}

Aboriginal Affairs and Northern Development Canada. (2012). Aboriginal Peoples and Communities. URL: http://pse5esd5.ainc-inac.gc.ca/FNP/Main/Search/FNRegPopulation.aspx?BAND_NUMBER=275\&lang=eng [November 19, 2012].

Ahern, M., Kovats, R.S., Wilkinson, P., Few, R., \& Matthies, F. (2004). Global Health Impacts of Floods: Epidemiologic Evidence. Epidemiologic Reviews, 27(1), 36-46.

Ballard, M. (2012). Flooding sustainable livelihoods of the Lake St Martin First Nation: The need to enhance the role of gender and language in Anishinaabe knowledge systems. (Unpublished doctoral dissertation). Natural Resources Institute, University of Manitoba, Winnipeg, MB.

Ballard, M., Klatt, R., \& Thompson, S. (2012). Flooding Hope: The Lake St. Martin First Nation story [Video]. URL: http://www.youtube.com/watch?v=SQStePF5jeg [May 2, 2013].

Beeston, L. (2011, December 22). A rough road for this pup: Last of the Lake St. Martin orphans at humane society. Winnipeg Free Press. URL: http://www.winnipegfreepress.com/local/a-rough-road-for-this-pup136054473.html [May 2, 2013].

Brocklesbury, M. \& Fisher, A. (2003). Community development in sustainable livelihoods approaches: An introduction. Community Development Journal, 38(3), 185-98.

Carney, D. (1998). Sustainable rural livelihoods: What contribution can we make? Papers presented at the Department for International Development's Natural Resources Advisers' Conference, July 1998. London, U.K.: Department for International Development.

Carney, D. (2002). Sustainable Livelihoods Approaches: Progress and possibilities for change. London, U.K.: Department for International Development. 


\section{Ballard \& Thompson (2013)}

Chambers, R. \& Conway, G. (1991). Sustainable rural livelihoods: practical concepts for the 21st century. Institute of Devlopment Studies, Discussion Paper 296. URL: http://www.ids.ac.uk/files/Dp296.pdf [May 2, 2013].

Clark \& Carney. (2008). Sustainable Livelihoods Approaches: What have we learnt?: A review of DFID's experience with Sustainable Livelihoods. Economic and Social Research Council. Research Seminar Paper.

Davidson-Hunt, I., Turner, K. L., Mead, A. T. P., Cabrera-Lopez, J., Bolton, R. Idrobo, C. J., Miretski, I. Morrison, A., \& Robson, J. P. (2012). Biocultural Design: A New Conceptual Framework for Sustainable Development in Rural Indigenous and Local Communities. IUCN Commissions, 5(2), 33-45.

Department for International Development (DFID). (2001). Sustainable livelihoods guidance sheets. URL: http://www.eldis .org/vfile/upload/1/document/0901/section2.pdf [May 2, 2013].

DFID. (2008). Development: Making it happen (Annual Report). URL: http://uww.official-documents.gov.uk/documenthc0708/ hc04/0492/0492.pdf [May 2, 2013].

Douglas, D.J.A. (1994). Community economic development in Canada. Toronto, ON: McGraw-Hill Ryerson.

Ellis, F. (2000). Rural livelihoods and diversity in developing countries. Oxford, U.K.: Oxford University Press.

Galloway, G. (2012, November 24). Flooded out to save Winnipeg, Lake St. Martin residents now feel forgotten. The Globe and Mail, F1.

Halla, F. (2007). A SWOT analysis of strategic urban development planning: The case of Dar es Salaam city in Tanzania. Habitat International 31(1), 130-42.

Hoch, C., Dalton, L., So, F., \& ICMA. (2000). The Practice of Local Government Planning (3rd ed.) Washington, DC: International City / County Management Association.

IMM. (2008). Sustainable livelihoods enhancement and diversification (SLED): A manual for practitioners. Gland, Switzerland: International Union for Conservation of Nature.

KGS Group \& AECOM. (2011). Analysis of options for emergency reduction of Lake Manitoba and Lake St. Martin levels. Winnipeg, MB: Manitoba Infrastructure and Transportation.

LaDuke, W. (2002). The Winona LaDuke Reader: A Collection of Essential Writings. Stillwater, MN: Voyageur Press.

Loney, M. (1995). Social problems, community trauma and hydro project impacts. Canadian Journal of Native Studies, 15(2), 231-54.

Loxley, J. (1986). The Economics of Community Development. Ottawa, ON: Native Economic Development Program.

Maser, C. (1996). Sustainable Community Development: Principles and concepts. Delray, FL: St. Lucie Press.

Province of Manitoba (2012). Flood Outlook Forecast Map. URL: http://www.gov.mb.ca/mitfloodinfo/floodoutlook/forecast_ centre/lakes/lake_levels/2010/lake_st_martin_levels_2011-12.pdf [November 19, 2012].

Scoones, I. (1998). Sustainable rural livelihoods a framework for analysis.

Institute of Development Studies, Working Paper 72. URL: http://www.ids.ac.uk/files/dmfile/Wp72.pdf [October 2011].

Shragge, E. (2003). Activism and social change: Lessons for community and local organizing. Toronto, ON: Broadview Press.

Southern Chiefs' Organization (SCO). (2012). Resolution \#5. SCO Flood Affected First Nations-Partnerships with Natural Resources Institute, University of Manitoba, to Conduct a Needs Assessment of Flood Affected Communities. Passed May 2012, Brokenhead, MB.

Terrados, J., Almonacid, G. \& Hontoria, L. (2007). Regional energy planning through SWOT analysis and strategic planning tools: Impact on renewables development. Renewable and Sustainable Energy Reviews, 11(6), 1275-87.

Thompson, S., Gulrukh, A., \& A. Murthy. (2011a). Back to Traditional Aboriginal Food. Alternatives Journal 37(2), 13.

Thompson, S., Lozeznik, V., \& Klatt, R. (Editor). (2011b). Harvesting Hope in Northern Manitoba Communities [Video]. URL: http://home.cc.umanitoba.ca/ thompso4/harvestinghope_doc.html [May 2, 2013]. 


\section{Ballard \& Thompson (2013)}

Thompson, S., Gulrukh, A., Ballard, M., Beardy, B., Islam, D., Lozeznik, V., \& Wong (2011c). Is community economic development putting healthy food on the table? Food Sovereignty in Northern Manitoba's Aboriginal communities. Journal for Aboriginal Economic Development, 7(2), 14-39.

Thompson S., Kamal, A. G., Alam, M. A., \& Wiebe, J. (2012). Community development to feed the family in Northern Manitoba Communities: Evaluating food activities based on their food sovereignty, food security, and sustainable livelihood outcomes. Canadian Journal of Nonprofit and Social Economy Research, 3(2), 43-66.

Thompson, S. \& Lozeznik, V. (2012). Harvesting Hope in Northern Manitoba: Can participatory video help rebuild Aboriginal Food Sovereignty? Women and Environment International Magazine, 88, 10-13.

Traverse, M. (1999). Analyzing the Effects of the Fairford Dam on Lake St. Martin First Nation. (Unpublished masters thesis). Department of Native Studies, University of Manitoba, Winnipeg, MB.

Vonk, G., Geertman, S. \& Schot, P. P. (2007). A SWOT analysis of planning support systems. Environment and Planning A, 39, 1699-714.

Waldram, J. (1993). As Long As the River Runs: Hydroelectric development and native communities. Winnipeg, MB: University of Manitoba Press.

Wakefield, G. \& Cottone, L. P. (1986). Education for the '80s and beyond. Public Relations Review Volume 12(2), 37-46.

Winnipeg Humane Society. (2012). Winnipeg Human Society. URL: http://www.winnipeghumanesociety.ca/files/ newsletters/WHSWinter2012small.pdf [May 2, 2013].

World Health Organization (2001). The world health report 2001-mental health: new understanding, new hope. Geneva, Switzerland: World Health Organization.

\section{ABOUT THE AUTHORS / LES AUTEURS}

Myrle Ballard is a PhD graduate, in the Natural Resources Institute, University of Manitoba. Email: ballamyr@gmail.com

Shirley Thompson is an Associate Professor, Natural Resources Institute, University of Manitoba. Email: s.thompson@ad.umanitoba.ca 